\title{
Guidelines for Low-Cost, Energy-Efficient House in Iraq
}

\author{
Udo Dietrich $^{1}$, Saif Rashid ${ }^{2}$ and Wolfgang Willkomm ${ }^{1}$ \\ 1. Research Group on Resource Efficiency in Architecture and Planning, HafenCity University, Hamburg 20457, Germany \\ 2. Department of Building Physics and Building Energy Optimisation, Technical University of Kaiserslautern, Kaiserslautern 67663, \\ Germany
}

\begin{abstract}
The goal of this study is to determine specific guidelines for Iraqi architects to contribute to the design and composition of energy-efficient housing units within the limits of a normal budget, locally available materials and technologies. These units can provide comfort despite the current energy situation in Iraq. The study is based on a computer simulation for a reference building in Baghdad, which has been selected according to the urban conditions, building legislations, housing market and statistics. The final results displayed the main recommendations and the possibility to achieve up to $50 \%$ energy reduction with a pay-back period not exceeding two years in some cases. There are some measures that have big energy saving potential. Yet, some of the measures may require big investment or have some bad environmental impacts. Some other good measures are already being implemented.
\end{abstract}

Key words: Iraq, housing, energy-efficiency, cost, simulation, optimization, material, heating and cooling.

\section{Introduction}

\subsection{City Study}

The Republic of Iraq is a country situated in west Asia with a total area of $434,128 \mathrm{~km}^{2}$ and an estimated population of $32,665,000$. In $2009,66 \%$ of Iraqi citizens were living in cities and urban areas [1]. Baghdad is the capital and the largest city hosting an estimated population of 8 million [2].

\subsection{Housing and Energy Problems}

The provision of housing represents one of the largest challenges in Baghdad and in Iraq as a whole. The estimated housing need in Iraq over the 10-year period from 2006 to 2016 is about 1.27 million units in urban areas [3]. By 2020, population of Iraq is expected to reach 40 million inhabitants [4]. In Iraq, $27 \%$ of households do not have shelter, about $30 \%$ of households in Iraq experience at least two slum-like conditions according to a survey conducted by UN-Habitat (United Nations Human Settlements

\footnotetext{
Corresponding author: Udo Dietrich, Dr., professor, research field: building physics. E-mail: udo.dietrich@hcu-hamburg.de.
}

Programme), and about $13 \%$ experience three or more slum-like conditions [3].

Due to decades of war and sanctions, Iraq generates about $50 \%$ of its demand with average 8,000 megawatts generated power compared to 15,000 megawatt power demand ${ }^{1}$. Iraqis pay extra fees to private generators and the electricity price from these generators is relatively high with 8-hour daily supply power of one kilowatts (costs about 50 USD per month $)^{2}$.

\subsection{Baghdad Climate}

According to Köppen Geiger map of world climate, Baghdad lies in the hot arid desert region Bwh (Bw: desert climate, h: low-latitude climate (average annual temperature above $18^{\circ} \mathrm{C}$ )) [5]. Due to the lack of up to date weather data in Baghdad, weather data was obtained from Autodesk ${ }^{\circledR}$ Green Building Studio web-based tool which provides weather data for virtual stations in areas where actual data are missing. In Baghdad, dry bulb temperature ranges between a maximum of $48{ }^{\circ} \mathrm{C}$ in summer days and a minimum

\footnotetext{
${ }^{1}$ Electricity Factsheet, IAU (Inter Agency Information and Analysis Unit), Iraq, 2010.

${ }^{2}$ S. Rashid, local market analysis, 2012.
} 
temperature blow $0{ }^{\circ} \mathrm{C}$ in the coldest winter nights [6]. Fig. 1 shows the hourly temperature profile and comfort-thermal neutrality.

Baghdad has a clear sky with average cloud range less than $30 \%$ and the relative humidity is low especially in summer [7]. The prevailing wind comes from north-west which sometimes brings sand storms from the western desert. However, there is also the south-eastern wind locally known as Sharji-Arabic for eastern. The wind speed is between $1 \sim 2 \mathrm{~m} / \mathrm{s}$ except when sand storms blow [6].

\section{Focus Building}

To deal with missing information of energy demand, a computer simulation using ECOTECT $^{\circledR}$ software

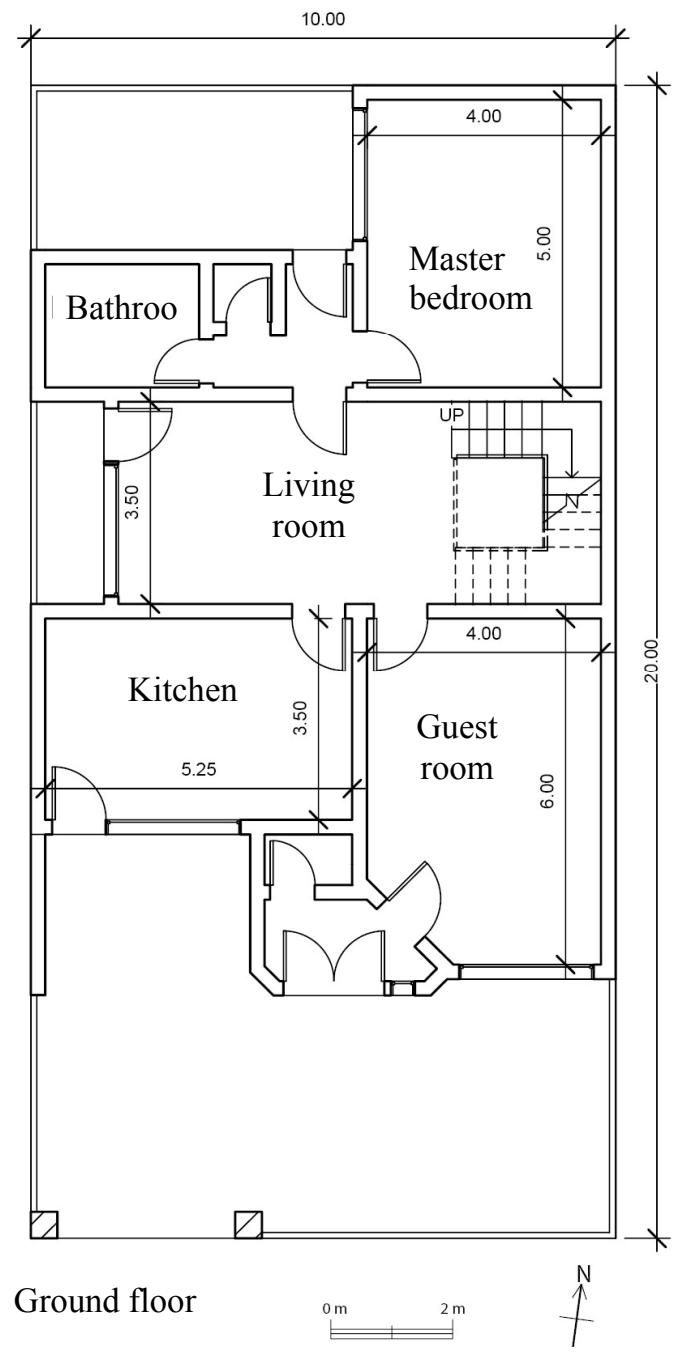

Fig. 1 Reference building floor plans. was performed to calculate the energy demand for a "reference building". As a reference building, a single family house was selected. The selection was based on analyzing building legislations, urban situation, building material, and market and construction industry. The house is designed for a family with $6 \sim 7$ members with five bedrooms, a kitchen, living room, guest room, two bathrooms and three small water closets. It also has a garage, a garden and a small courtyard. The house is attached with south-north orientation and main facade facing south.

Looking at the construction material and details, the house is to be built with $24-\mathrm{cm}$ brick load bearing walls with gypsum plaster as interior finish and stone-cladding as exterior finish. The roof is $15-\mathrm{cm}$

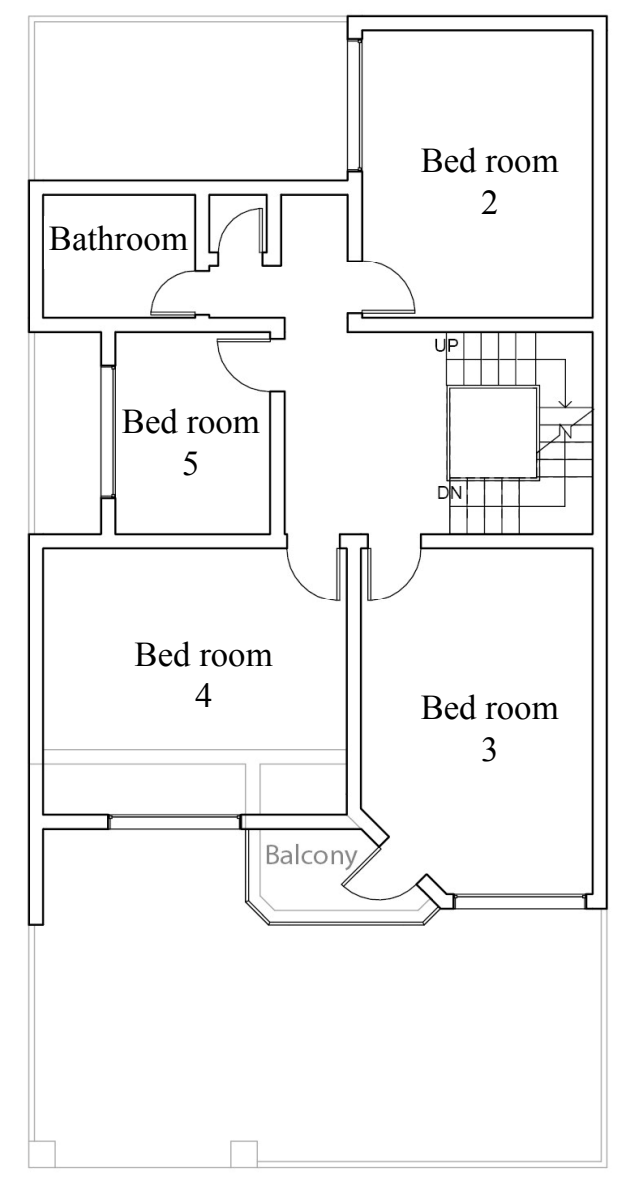

First floor 
reinforced concrete slab with insulation, water protection, sand and concrete tiles on top. Windows used are single glazed with aluminum frames and protection grilles. The heating and cooling load for the building were $43.68 \mathrm{kWh} / \mathrm{m}^{2} \mathrm{a}$ and $98.09 \mathrm{kWh} / \mathrm{m}^{2} \mathrm{a}$ respectively with maximum heating power of $9,608 \mathrm{~W}$ at 08:00 on January 13th and max cooling power of $16,989 \mathrm{~W}$ at 15:00 on September $16 \mathrm{th}^{3}$.

\section{Building Optimisation}

A look at the psychrometric chart (Fig. 2) shows some of the measures to be implemented to optimise the building such as thermal mass, shading and passive solar gains. However, this section will deal only with the reduction of loads without including HVAC (heating, ventilation and air conditioning system).

\subsection{Air Tightness}

In the simulation of the reference building, air change rate (indicating air tightness) was set to 2.0 air change per hour. Ventilation counts for $37.4 \%$ of the total losses and $12.1 \%$ of the heat gains. By improving windows' air tightness and the way they are fixed on the wall, there's a significant reduction especially in the heating load. Better air tightness is also helpful to reduce the effect of sand storms.

\subsection{Building Material}

An array of possible building materials were used to reach the optimum choice, and material changes include the walls, roofs and finishing material with or without insulation. Material choice is based on the available material on the market. For exterior walls (facade walls), four different wall types were tested: brick wall (24 cm thick) with cement rendering as exterior finishing, brick wall $(24 \mathrm{~cm})$ with stone cladding ( $5 \mathrm{~cm}$ gap between the stone and the brick either left as air-gap or filled with glass-wool) and

${ }^{3}$ ECOTECT $^{\circledR}$ Analysis, building simulation by author using ECOTECT $^{\circledR}$ software, 2012.
ICF (insulated concrete form) which consists of a 12 $\mathrm{cm}$ concrete filling the gap between two layers of polystyrene with thickness of $6 \mathrm{~cm}$ each and cement panel as exterior finish. The roof construction includes the slab (concrete or brick arches), damp proof layers, sand (for the slope), tiles and sometimes insulation layer [8]. Table 1 shows the thermal loads for the alternatives.

The most efficient material alternative was the ICF structure with double glazed windows [8]. However, the ICF structure is a concrete construction which is highly energy intensive in the production phase which may make it not the best alternative if the whole process is taken into account. It is also not very widespread because it is relatively new in the market and there is only one factory in Iraq.

\subsection{Windows}

Single- and double-glazed windows were tested as window types. Furthermore, windows size and position were also subject to changes, which were based on research papers conducted mainly by Dr. Miqdad Aljawadi about the effect window position, shape and size in providing shade in summer. In the reference building, the window sizes are large reflecting the general trend. Windows of the house are facing different orientations, the main facade faces south, while the backyard windows face north and west and, in the courtyard, west oriented windows are used. South facing windows function better if horizontal because the sun angle in summer is very high. In case of vertical windows, it is recommended to divide the height into smaller windows [9].

The windows used in the south facade are big with $2.4 \mathrm{~m}$ in width and $1.2 \mathrm{~m}$ in height. It is proposed to use smaller windows, $2 \mathrm{~m}$ in width and $1.1 \mathrm{~m}$ in height. Generally, when windows are facing north, vertical windows are preferred and the use of several smaller windows is better than a single large one [9]. However, in the house, north facing windows are only the small bathroom windows. West facing windows 


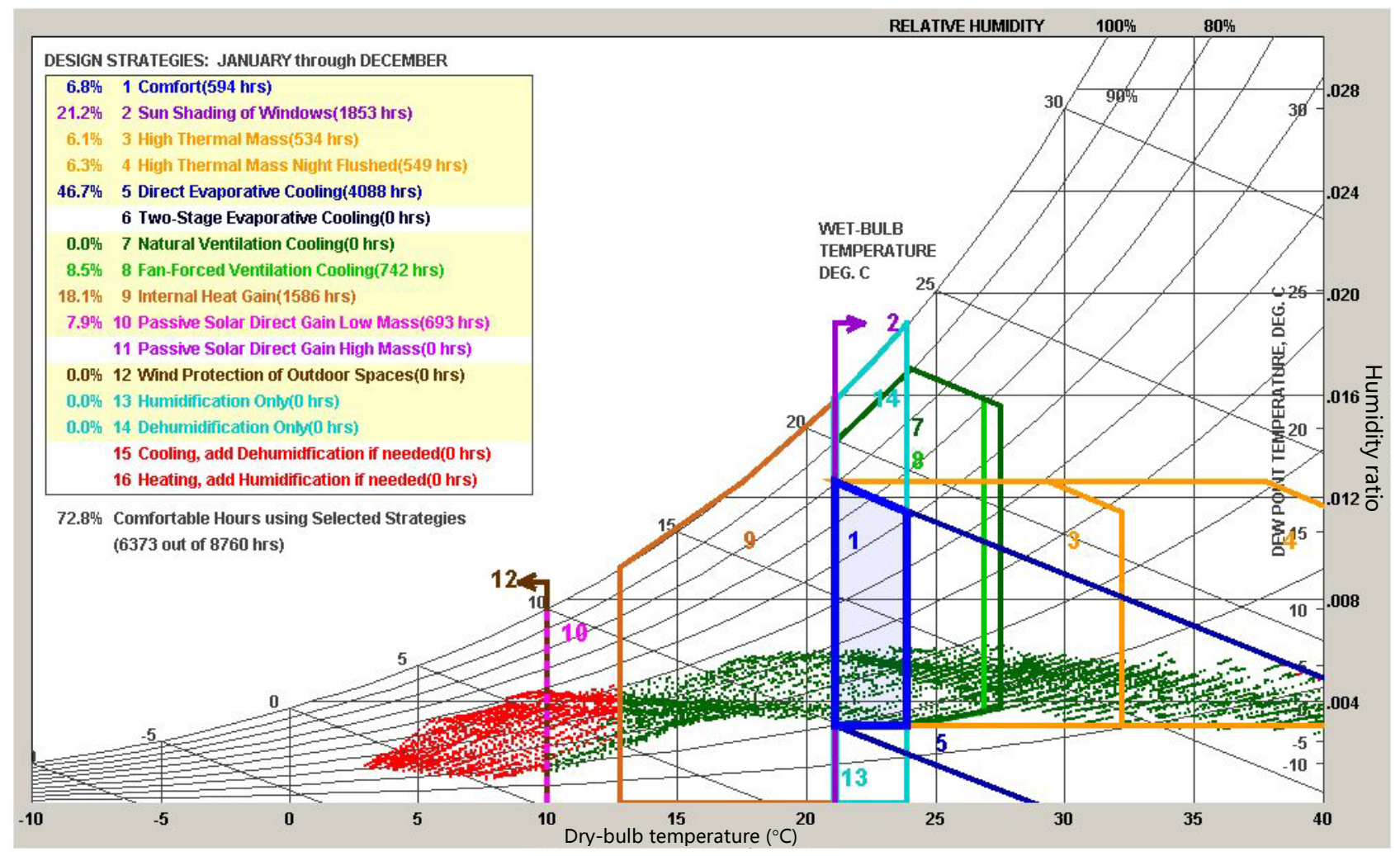

Fig. 2 Psychrometric chart showing comfort limits and passive design measures.

Table 1 Heating and cooling loads for different wall and roof types.

\begin{tabular}{|c|c|c|c|c|c|}
\hline \multirow{2}{*}{ Wall } & \multirow{2}{*}{ Roof } & \multirow{2}{*}{ Window } & \multirow{2}{*}{ Air change rate (air change/h) } & \multicolumn{2}{|c|}{ Thermal load $\left(\mathrm{kW} / \mathrm{m}^{2} \mathrm{~h}\right)$} \\
\hline & & & & Heating & Cooling \\
\hline \multirow{4}{*}{$\begin{array}{l}\text { Brick wall } 24 \mathrm{~cm}+ \\
\text { render }\end{array}$} & \multirow{4}{*}{ Reinforced concrete } & \multirow{2}{*}{ Single glazed } & 2.0 & 44.68 & 100.09 \\
\hline & & & 0.5 & 25.27 & 82.52 \\
\hline & & \multirow{2}{*}{ Double glazed } & 2.0 & 38.91 & 87.63 \\
\hline & & & 0.5 & 19.38 & 70.43 \\
\hline \multirow{8}{*}{$\begin{array}{l}\text { Brick wall } 24 \mathrm{~cm}+ \\
\text { stone cladding }\end{array}$} & \multirow{4}{*}{ Reinforced concrete } & \multirow{2}{*}{ Single glazed } & 2.0 & 43.68 & 98.09 \\
\hline & & & 0.5 & 24.09 & 80.66 \\
\hline & & \multirow{2}{*}{ Double glazed } & 2.0 & 37.69 & 85.74 \\
\hline & & & 0.5 & 18.05 & 68.84 \\
\hline & \multirow{4}{*}{ Jack arch brick } & \multirow{2}{*}{ Single glazed } & 2.0 & 45.96 & 102.68 \\
\hline & & & 0.5 & 26.26 & 85.48 \\
\hline & & \multirow{2}{*}{ Double Glazed } & 2.0 & 40.04 & 90.37 \\
\hline & & & 0.5 & 20.10 & 73.67 \\
\hline \multirow{4}{*}{$\begin{array}{l}\text { Brick wall } 24 \mathrm{~cm}+ \\
\text { insulation }+ \text { stone } \\
\text { cladding }\end{array}$} & \multirow{4}{*}{ Reinforced concrete } & \multirow{2}{*}{ Single glazed } & 2.0 & 43.08 & 97.59 \\
\hline & & & 0.5 & 23.52 & 80.48 \\
\hline & & \multirow{2}{*}{ Double glazed } & 2.0 & 36.98 & 85.70 \\
\hline & & & 0.5 & 17.01 & 69.81 \\
\hline \multirow{4}{*}{ ICF } & \multirow{4}{*}{ Reinforced concrete } & \multirow{2}{*}{ Single glazed } & 2.0 & 35.24 & 83.77 \\
\hline & & & 0.5 & 16.24 & 66.23 \\
\hline & & \multirow{2}{*}{ Double glazed } & 2.0 & 29.25 & 71.45 \\
\hline & & & 0.5 & 16.45 & 64.58 \\
\hline
\end{tabular}


Table 2 Heating and cooling load building material and optimized windows.

\begin{tabular}{|c|c|c|c|c|c|}
\hline \multirow{2}{*}{ Wall } & \multirow{2}{*}{ Roof } & \multirow{2}{*}{ Window } & \multirow{2}{*}{ Air change rate (air change/h) } & \multicolumn{2}{|c|}{ Thermal load $\left(\mathrm{KW} / \mathrm{m}^{2} \mathrm{~h}\right)$} \\
\hline & & & & Heating & Cooling \\
\hline \multirow{4}{*}{$\begin{array}{l}\text { Brick wall } 24 \mathrm{~cm}+\text { stone } \\
\text { cladding }\end{array}$} & \multirow{2}{*}{ Reinforced concrete } & Single & 2.0 & 41.55 & 96.84 \\
\hline & & Double & 0.5 & 17.06 & 69.01 \\
\hline & \multirow{2}{*}{ Jack arch brick } & Single & 2.0 & 44.12 & 98.60 \\
\hline & & Double & 0.5 & 18.52 & 72.96 \\
\hline \multirow{2}{*}{$\begin{array}{l}\text { Brick wall } 24 \mathrm{~cm}+\text { insulation } \\
+ \text { stone cladding }\end{array}$} & \multirow{2}{*}{ Reinforced concrete } & Single & 2.0 & 41.45 & 93.35 \\
\hline & & Double & 0.5 & 16.04 & 68.42 \\
\hline \multirow{2}{*}{ ICF } & \multirow{2}{*}{ Reinforced concrete } & Single & 2.0 & 34.10 & 79.86 \\
\hline & & Double & 0.5 & 9.50 & 53.74 \\
\hline \multirow{2}{*}{$\begin{array}{l}\text { Brick wall } 36 \mathrm{~cm}+\text { stone } \\
\text { cladding }\end{array}$} & \multirow{2}{*}{ Reinforced concrete } & Single & 2.0 & 41.48 & 96.94 \\
\hline & & Double & 0.5 & 12.31 & 61.81 \\
\hline
\end{tabular}

\section{Vertical design} angle $($ March 22nd $)=57^{\circ}$

Fig. 3 Window grill/shading louver.

are also preferred to be horizontal, therefore similar windows' dimensions were proposed for the windows facing the courtyard and the backyard.

As can be seen in Table 2, the use of single- and double-glazing was also tested, and the results show that using double glazed windows has influence with similar percentages on both heating and cooling load. Windows are placed on the interior edge of the opening, in this case, the lintel and edges provide shading for the window, thus, reduces the direct solar gains [10].

\subsection{Shading Devices}

Shading devices could be fixed on overhangs, louvers or operable sunshades. Overhangs already exist in the reference building design but not for all windows. Operable shades might not be preferred aesthetically. For the rest of windows, it is possible to use an array of small scale louvers by redesigning the windows' grilles which are typically used for security purposes.

The louvers have a shading coefficient of $100 \%$ in summer and $32 \%$ in winter [11]. However, the added louvers do not provide a remarkable improvement on energy demand in this case because most of the windows in the reference building are already shaded by other masses. Fig. 3 shows a detail of the proposed window grill ${ }^{4}$.

\subsection{Other Measures}

There are additional measures to reduce the energy demand (especially cooling), the effect of these measures might not be high but, together with other measures, there could be a significant improvement. These measures include the use of light colors, trees, vegetation and changes in the building's zones.

\section{Scenarios}

In this part, different scenarios for heating and cooling systems will be developed. A comparison between the scenarios will be implemented based on simplified economic estimations to reach the optimum system: the economic balance will include construction costs, HVAC cost, operation and other costs.

\subsection{Reference Building}

As noted above, the heating and cooling loads for the reference building are $43.68 \mathrm{kWh} / \mathrm{m}^{2} \mathrm{a}$ and 98.09

${ }^{4}$ Ibid 3 . 
$\mathrm{kWh} / \mathrm{m}^{2} \mathrm{a}$. Free-running building simulation showed that about $60 \%$ of the hours exceed adaptive comfort limit which includes a human factor assuming that people would change behavior when temperature exceeds the limits to restore comfort based on Humphreys and Nicol (1998) model, therefore having an adaptive building here is not possible and the building has to be air conditioned.

Sizing the AC (air conditioner) split units is based on the simulation results for maximum heating and cooling, the size will be displayed in ton of refrigeration $(3.52 \mathrm{~kW})$ for each room and assuming a coefficient of performance of about 2.6, and the energy demand will be calculated by converting the power needed into amperage, knowing that the electricity grid in Iraq has a voltage of $220 \mathrm{v}$. Table 3 shows a rough estimation for the investment in constructing the reference building (including the AC units).

As noted above, the energy cost is calculated based on the maximum power which is how electricity from private generators is priced. Price of electricity from private-owned neighborhood generators is amperage-based, for instance, a daily supply of eight hours with five amperes current costs 50 USD per month, 10 amperes would cost 100 USD and so on ${ }^{5}$. The reference building in this case would consume about 7,965 W or 36 amp only for cooling and 4,451 $\mathrm{W}$ or $20 \mathrm{amp}$ for heating in winter excluding other uses. In a simplified calculation, assuming that electricity from private generator is needed 16 hours a day, the monthly price will be 20 USD per ampere, translated to an annual cost of 5,520 USD only for providing comfort.

\subsection{Optimized Brick Walls: $36 \mathrm{~cm}$}

In this building, thicker exterior walls are used with double glazed windows and better air tightness. The living room will be smaller because of the partition that isolates the stair case from the room. The use of

${ }^{5}$ Ibid 2.
$36 \mathrm{~cm}$ thick walls will be more cost intensive in terms of material as well as labor. In this case, the cost of the structure is estimated to be $240 \mathrm{USD} / \mathrm{m}^{2}$, the double glazed windows have extra cost of about 30 $\mathrm{USD} / \mathrm{m}^{2}$. Moreover, the grilles/shading louvers will have a cost of $50 \mathrm{USD} / \mathrm{m}^{2}$.

For cooling, it is possible to use split-unit $\mathrm{AC}$ or evaporative coolers while AC or electric or oil heaters can be used in winter for heating. As show in Table 3, the construction cost was roughly estimated for this scenario, this time, including the cost of air conditioners or evaporative coolers and oil.

In this scenario, the construction cost when $\mathrm{AC}$ units and evaporative coolers are used goes up to 123,913.25 USD and 122,783.25 USD, respectively, and the annual energy cost goes down to 2,700 USD when split-unit ACs are used and 1,800 USD with evaporative cooler and electric heater, and 620 USD with evaporative cooler and oil heater.

\subsection{Optimized ICF Walls}

ICF walls would have no difference in thickness compared to reference building, but better air tightness and double glazed windows and the wall layers perform better. Compared to "conventional" brick construction, the cost of ICF structure is lower thanks to the lower labor cost and the market preference for brick. The total construction cost (including $\mathrm{AC}$ or evaporative cooler and electric heaters) would be slightly more with 10,8423.6 USD and 106,693.6 USD. In this case, the AC sizes are the same as the previous alternative, and the energy cost will be similar, which also applies for the evaporative cooler. The only exception is the heating cost. As the heating load is less, so are the heating hours, as a result, with oil heating, $263 \mathrm{~L}$ are needed which cost 13 USD if normal rates are applied and 780 USD if electricity is used for heating.

\section{Results and Discussions}

Based on the estimations of all three parameters 
Table 3 Construction costs in USD for reference building.

\begin{tabular}{lllll}
\hline & Quantity & Unit & Cost (USD/unit) & Total cost (USD) \\
\hline Structure & 254.7 & $\mathrm{~m}^{2} \mathrm{f} \cdot \mathrm{a}$ & 180 & 45,846 \\
Facade & 41.53 & $\mathrm{~m}^{2}$ & 25 & $1,038.25$ \\
Windows & 33.1 & $\mathrm{~m}^{2}$ & 50 & 1,655 \\
\hline \multirow{2}{*}{ Doors } & 16 & Item & 180 & 2,880 \\
& 1 & Item & 300 & 300 \\
\hline Floor finish & 288 & $\mathrm{~m}^{2}$ & 18 & 5,184 \\
\hline \multirow{2}{*}{ Plumbing } & 28 & Plug & 160 & 4,480 \\
& 1 & - & - & 2,000 \\
\hline \multirow{2}{*}{ Electrical } & 76 & Plug & 100 & 7,600 \\
\hline Other & 1 & - & - & 3,000 \\
\hline & 1 & & 30,000 & 30,000 \\
AC & 2 & Unit $0.5 \mathrm{t}$ & 250 & 500 \\
& 3 & Unit $0.75 \mathrm{t}$ & 280 & 840 \\
\hline Total & 1 & Unit $1 \mathrm{t}$ & 310 & 620 \\
\hline
\end{tabular}

ICF/EC-electric heater

ICF/EC-oil heater/ground water*

ICF/EC-oil heater
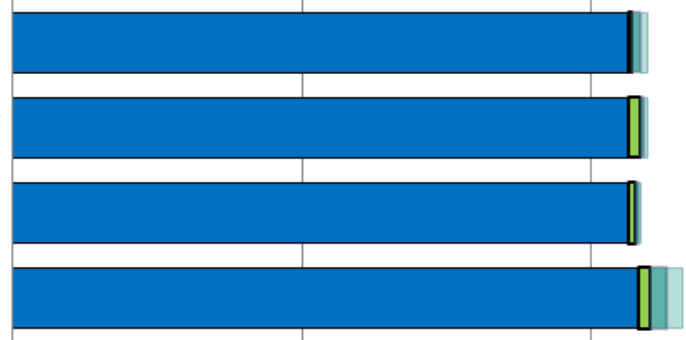

Building construction

$\mathrm{ICF} / \mathrm{AC}$

36-brick/EC-electric heater

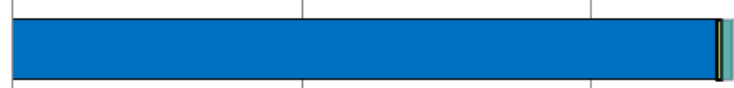

口HVAC

Energy 1 year

36-brick/EC-oil heater/ground water*

36-brick/EC-oil heater

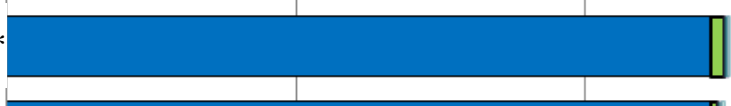

Energy 2 years

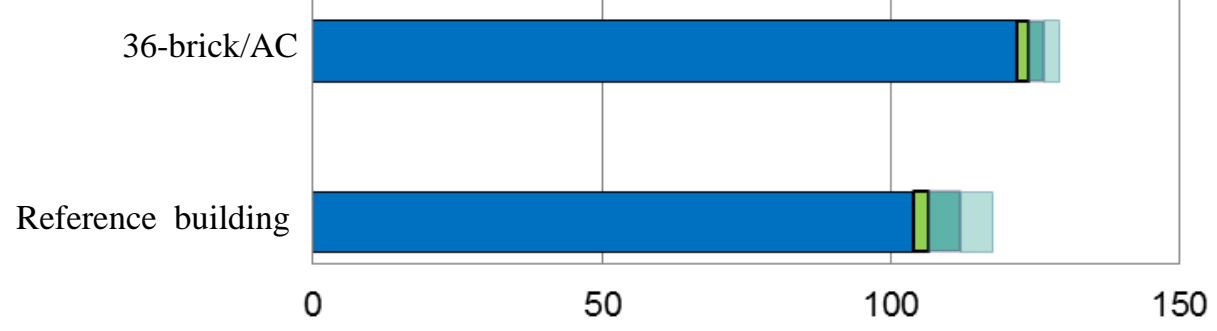

* stands for Incl. 1,000 USD rough cost for ground water.

Fig. 4 Investment and operation cost for first and second years.

abovementioned, Fig. 4 displays the total investment and current energy cost from private generators. The figure shows that ICF alternative pays back within the first year considering the prices from the private generators. It is hard to define a longer period for investment because of the expected improvement in electricity sector. Nevertheless, when the supply will be close to cover the demand, there are plans for new prices mechanism to strengthen the Ministry of Electricity.

\section{Conclusions}

By defining the points with the largest potential and 
Table 4 Energy saving potential of different measures.

\begin{tabular}{|c|c|c|c|c|}
\hline \multirow{2}{*}{ Measure } & \multicolumn{2}{|c|}{ Energy saving } & \multirow{2}{*}{$-\operatorname{Cost} *$} & \multirow{2}{*}{ Environmental impact } \\
\hline & Heating & Cooling & & \\
\hline Thermal Insulation & $5 \%$ & $5 \%$ & $+5 \%$ & \\
\hline Thicker Walls & $30 \%$ & $15 \%$ & $+25 \%$ & \\
\hline ICF & $50 \%$ & $20 \%$ & $-10 \%$ & $\begin{array}{l}\text { - energy in production } \\
\text { - thermal mass discontinuity } \\
\text { - concrete recycling }\end{array}$ \\
\hline Air Tightness & $35-40 \%$ & $15-20 \%$ & - & air tightness \\
\hline Double Glazing & $20 \%$ & $15 \%$ & $+50 \%$ & + comfort \\
\hline Shading Devices** & - & $5 \%$ & $+50 \%$ & \\
\hline Window Size & $5 \%$ & $5 \%$ & $-30 \%$ & \\
\hline Color (white) & $-5 \%$ & $5 \%$ & - & \\
\hline Evaporative Cooler & - & $50 \%$ & $50 \%$ & $\begin{array}{l}+ \text { urban heat island } \\
\text { - water availability }\end{array}$ \\
\hline
\end{tabular}

choosing the optimum solution for the scenarios, it is possible to reduce the primary energy demand from $147.227 \mathrm{kWh} / \mathrm{m}^{2}$ a to $76.97 \mathrm{kWh} / \mathrm{m}^{2}$ a. Table 4 depicts a comparison between the different measures in terms of energy performance, cost and other environmental impacts to be taken into consideration.

By analyzing the reference building, some of the design strategies already used have a positive impact, e.g., building compactness, overhangs and roof insulation, and these measures can be further developed whereas some other design features can be modified and some other simple details can have a big impact. The final outcome when these measures are considered is distinctive but not bizarre.

The design measures and recommendations represent a working methodology which can be applied for designing different housing units with different requirements: these measures can also be implemented in renovating old building to improve comfort level. On the other hand, economic evaluation and comparison help the architect and developer in sharing the information with the client in understandable form and help in decision making.

The main challenge faced by this approach may be the unskilled labour and the cost, especially knowing that the loan for building a house does not exceed
$25 \%$ of the total construction. Consequently, people look for the cheapest solution without asking for the better. Another problem which is more an urban problem is the regulation and the tendency to own single-family houses which are not the most efficient alternatives.

\section{References}

[1] Encyclopædia Britannica, Encyclopædia Britannica, Inc. [Online], 2012, http://www.britannica.com/EBchecked/ topic/293631/Iraq\#toc22922 (accessed Jul. 18, 2012).

[2] Khatib \& Alami, Comprehensive Development Plan for Baghdad-Stage 1, Pacific Consultant, Mebex Iraq, 2008.

[3] Iraq Housing Market Study, UN-Habitat, 2006.

[4] Country Programme Document 2009-2011, UN-Habitat, 2009.

[5] M. Kottek, J. Grieser, C. Beck, B. Rudolf, F. Rubel, World map of the Köppen-Geiger climate classification updates, Meteorologische Zeitschrift 15 (2006) 259-263.

[6] A. Al-Musaed, A. Almssad, S. Harith, M. Nathir, M. Ameer, Shading effects upon cooling house strategy in Iraq, in: Proceedings of the 2nd PALENC (Passive and Low-Energy Cooling for Built Environment) Conference and the 28th AIVC (Air Infiltration and Ventilation Center) Conference, Greece, 2007, pp. 40-44.

[7] J. James, Green Building Studio-Design Tool, Hirsch \& Associates, USA, 2012.

[8] A. Al-suhairy, Building Construction, Ken'an Press, Baghdad, 1991. (in Arabic)

[9] M. Al-Jawadi, M. Al-Noah, The best window proportion 
in housing design for latitude $33^{\circ} \mathrm{N}$, in: Proceedings of IAHS (International Association for Housing Science) Conference, 1979, pp. 753-768.

[10] M. Al-Jawadi, F.A. Al-Sudani, B.S. Daahi, Effect of window position inside wall thickness on direct sunlight control in buildings for hot regions in Iraq, Arab Universities Journal of Engineering Sciences 8 (2) (2001) 81-100. (in Arabic)

[11] A.J. Marsh, Solar Tool Software, Autodesk ${ }^{\circledR}$ Inc., California, 2008. 